\title{
Significance of Lockeia and associated trace fossils from the Bada Bagh Member, Jaisalmer Formation, Rajasthan
}

\author{
Amruta R Paranjape, Kantimati G Kulkarni* and Shweta S Gurav \\ Geology and Palaeontology Group, Agharkar Research Institute, Pune 411004 , India. \\ ${ }^{*}$ Corresponding author. e-mail: kantimatik@gmail.com
}

\begin{abstract}
A Lockeia-Protovirgularia ichnofauna representing the Cruziana ichnofacies is reported from a calcareous sandstone horizon of the Callovian Bada Bagh Member, Jaisalmer Formation, Rajasthan. The ichnoassemblage is characterized by Lockeia cunctator, L. siliquaria, Protovirgularia ?bidirectionalis, P. rugosa, Ptychoplasma vagans along with Palaeophycus tubularis, P. striatus, Heliophycus isp. and ?Lophoctenium isp. Use of numerical analysis yielding length to width ratio, slopes and coefficient of determination helps in confirming identification of ichnospecies of Lockeia. Fine morphological details of Lockeia and Protovirgularia, especially sharp and closely spaced chevrons of Protovirgularia, indicate that the substrate in which they were emplaced was stiff, resistant, dewatered and better consolidated. Therefore, it construes that this ichnoassemblage belonging to the classical Cruziana ichnofacies occurs in stiff softground and not a typical softground. Though the ichnofacies of this calcareous sandstone bed indicates low-medium energy condition under subtidal environment of deposition, underlying strata containing Arenicolites, Skolithos and Curvolithus of Skolithos ichnofacies indicate intertidal sandy shore environment with high energy conditions. Thus, it is concluded that this area was undergoing continuous, gradual deepening. However, the percentage of Thalassinoides, Ophiomorpha and Phycodes in the overlying bed is quite high suggesting an increase in the energy conditions resulting from a probable shallowing.
\end{abstract}

\section{Introduction}

Ichnology comprises of processes involved in organism-substrate interaction and their resulting products, the traces themselves (Buatois and Mángano 2011). Hence, they are excellent indicators of sedimentation rates, substrate coherence, salinity, oxygen levels, turbidity, light, temperature and hydrodynamic energy. Also, they are good proxies for palaeoenvironmental interpretations as they are emplaced in situ.

The current paper reviews the ichnological data of one bed from Bada Bagh Member, exposed near Bada Bagh village on Jaisalmer-Ramgarh road (figure 1), and discusses on its palaeoecological and palaeoenvironmental interpretations. The current trace fossil suite is characterized by an exceptional assemblage exhibiting three ethological expressions of wedge and cleft footed bivalves. The three ethological classes, viz., cubichnia, repichnia and pascichnia are represented here by Lockeia, Protovirgularia, Ptychoplasma and ? Lophoctenium.

A similar trace fossil assemblage, representing deposition in foreshore to offshore environment, has been reported earlier from the coeval Middle Jurassic sediments of adjoining Kachchh basin (Joseph et al. 2012).

Keywords. Lockeia; Protovirgularia; Cruziana ichnofacies; Callovian; Jaisalmer Formation; Rajasthan. 


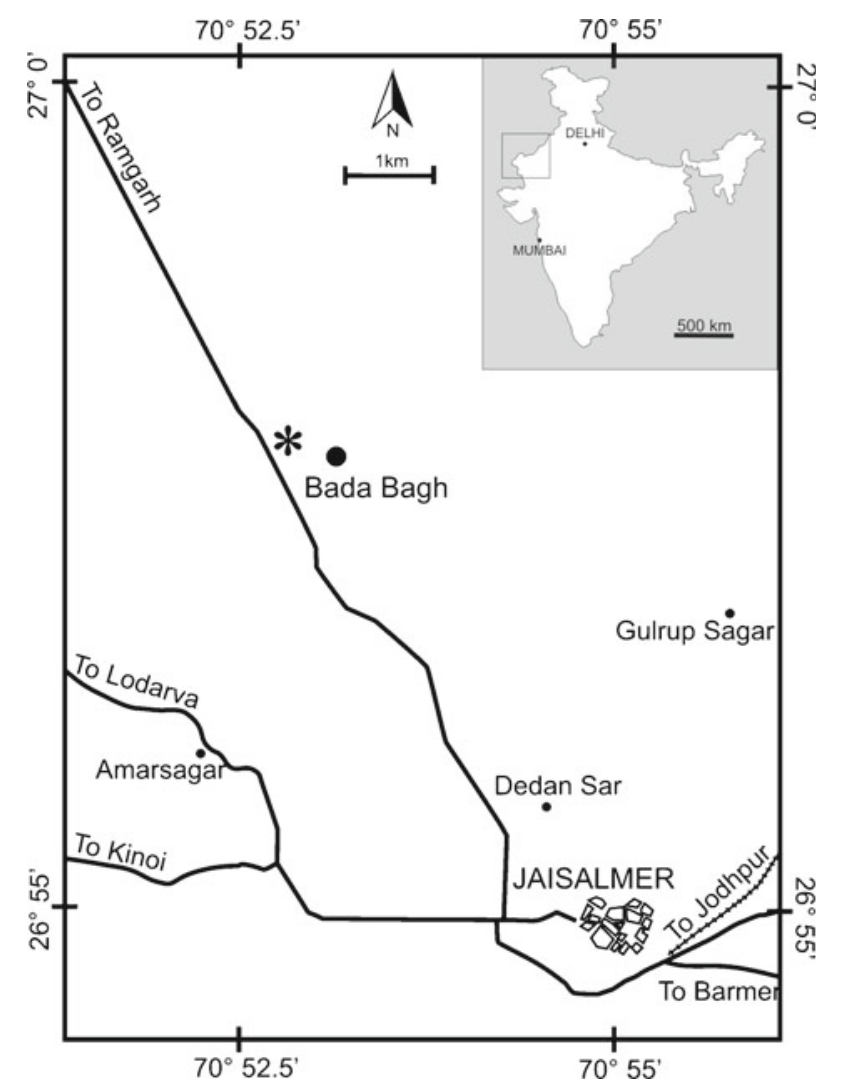

Figure 1. Location map. Collection site is marked by asterisk.

\section{Geological setting}

The Jaisalmer Formation lies in the southeastern part of the Jaisalmer Basin and is assigned a Callovian to Oxfordian age. Its thickness is $400 \mathrm{~m}$ (Das Gupta 1975; Singh 2006). Blanford (1877) and Oldham (1886) were amongst the first to study these marine Mesozoic rocks occurring in this region. The oldest sediments of the marine Mesozoic succession, now designated as the Jaisalmer Formation, were initially referred to as the 'Jaisalmer limestone' by Blanford (1877), who had divided it into four subdivisions, viz., Joyan, Fort, Bada Bagh and Kuldhar.

The first systematic account of trace fossils from the marine Mesozoic sediments was given by Kumar (1979). Ichnofaunal studies were followed by Gupta et al. (1966), Chiplonkar et al. (1981), Sudan et al. (2000), Borkar and Kulkarni (2001, 2002) and Pandey et al. (2010).

The lithostratigraphic classification of the Jaisalmer Formation proposed by Das Gupta (1975) is widely accepted. He divided it into five members, viz., Hamira, Joyan, Fort, Bada Bagh and Kuldhar. The predominant lithologies are limestones and calcarenites, deposited under shallow-marine conditions. The Jaisalmer Formation is underlain by the fluvial Lathi Formation comprised of sandstones and shales with abundant wood fragments and overlain by Baisakhi Formation predominantly of shales belonging to nearshore to shallow-marine environments.

The Bada Bagh Member begins with a thin layer of sandstone and an intrabasinal conglomerate, followed by shale, oolitic limestone and calcarenites. The calcarenites are yellowish buff in colour and highly fossiliferous. They show a lot of variation all through its thickness with regard to sand, fossil and carbonate content. The calcarenites are intercalated with numerous thin sandy and silty layers and show a diverse collection of trace fossils. The youngest bed of the Bada Bagh Member shows thin laminated layers with interference ripples, indicating close vicinity to the coast.

The Bada Bagh Member corresponds to zone 5 or the Limatula jaini, Falcimytilus sp., Coelastarte sp. zone of Kachhara and Jodhawat (1999) and is considered to be of Middle Callovian age. It is believed to be conformable with the underlying Fort Member and overlying Kuldhar Member (figure 2).

\section{Trace fossil assemblage}

\subsection{Studied material}

The ichnofauna dealt within the present communication comes from a stratum $27.25 \mathrm{~m}$ above the base of the Bada Bagh Member and is an integral part of the calcarenite litho-unit (figures 1 and 2). It is a coarse grained calcareous sandstone exhibiting low angle cross bedding.

The type specimens are housed in the fossil repository of the Agharkar Research Institute bearing the acronym MACS G (Maharashtra Association for the Cultivation of Science, Geology).

\subsection{Systematic taxonomy}

Ichnogenus Heliophycus Miller and Dyer 1878

Heliophycus isp. Miller and Dyer 1878

Plate 1(a)

Material: One specimen.

Plesiotype: MACS G 5186

Description: Star-like trace with five radiating arms preserved in convex hyporelief. Total diameter of the trace is $21 \mathrm{~mm}$. The central portion is circular, bulbous and undifferentiated with a diameter of $6 \mathrm{~mm}$. Five arms project radially outwards from it. They are $9-10 \mathrm{~mm}$ in length, triangular, broad at the base and tapering outwards. Width of the arms at the base is $4 \mathrm{~mm}$. The arms lack ornamentation.

Remarks: The present specimen small in size, with star-like triangular arms exhibits similar 


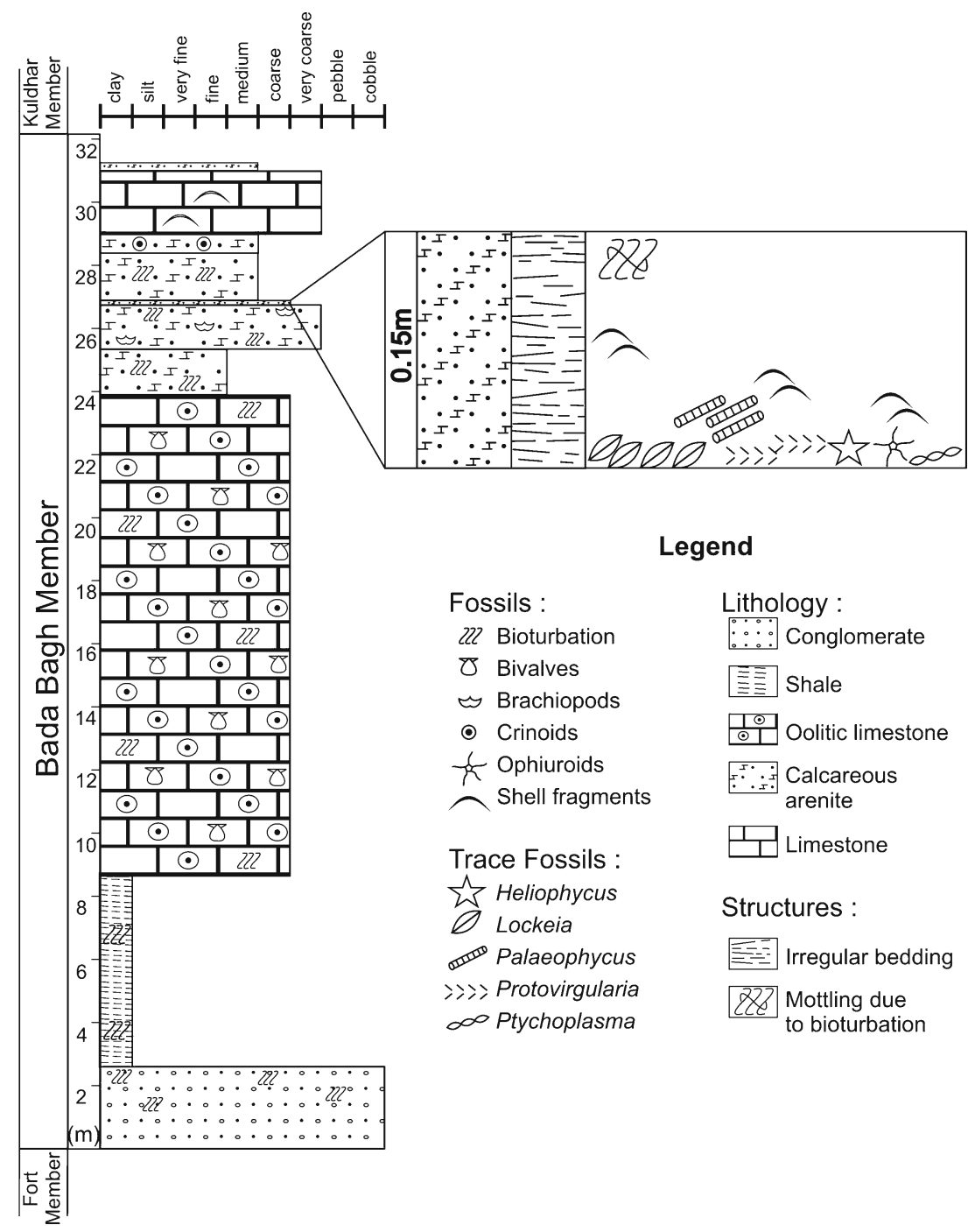

Figure 2. Litholog of Bada Bagh Member. Enlarged is the Lockeia bearing calcareous sandstone bed.

diagnostic features as Asteriacites lumbricalis Schlotheim 1820 (Seilacher 1953) as well as Heliophycus Miller and Dyer 1878 (Schlirf 2012). Schlirf (2012) considered Asteriacites to be a nomen dubium, the major reason in its defence being the unavailability of its type specimens. The authors agree with Schlirf (2012) and Bertling et al. (2006) that the diagnosis of an ichnotaxon should be independent of the producer and its interpretation. Also, a valid ichnotaxon name should be preferred over a popular nomenclature while identifying any trace fossil (Schlirf 2012). Thus, the authors favour the use of the ichnotaxon Heliophycus over Asteriacites.

Most of the earlier reported Asteriacites (now Heliophycus) occur in fine to silty sandstones with the exception of silty limestone (Wilson and Rigby 2000). But in the Bada Bagh Member, the trace is preserved in coarse-grained calcareous sandstone.
This could be the possible reason for the transverse striations not being preserved.

Two small ophiuroids found in the same bed (plate 1b) could have been the possible creators of this trace. Its close association with other bivalve traces, viz., Lockeia and Protovirgularia suggests predation on small molluscs (Mángano et al. 1999).

Ichnogenus Lockeia James 1879

Lockeia cunctator Schlirf and Uchman 2001

Plate $1(\mathrm{c}-\mathrm{f})$

Material: Two slabs containing 77 specimens.

Plesiotypes: MACS G 5188, MACS G 5189a

Description: Circular to oval traces in convex hyporelief. Each structure is $7-8 \mathrm{~mm}$ long and about $5 \mathrm{~mm}$ wide. Thickness is about $3-4 \mathrm{~mm}$. Except for a few, all other traces are attached to each other and seem to diverge in different directions from the same axis. The clusters (plate 1c), 

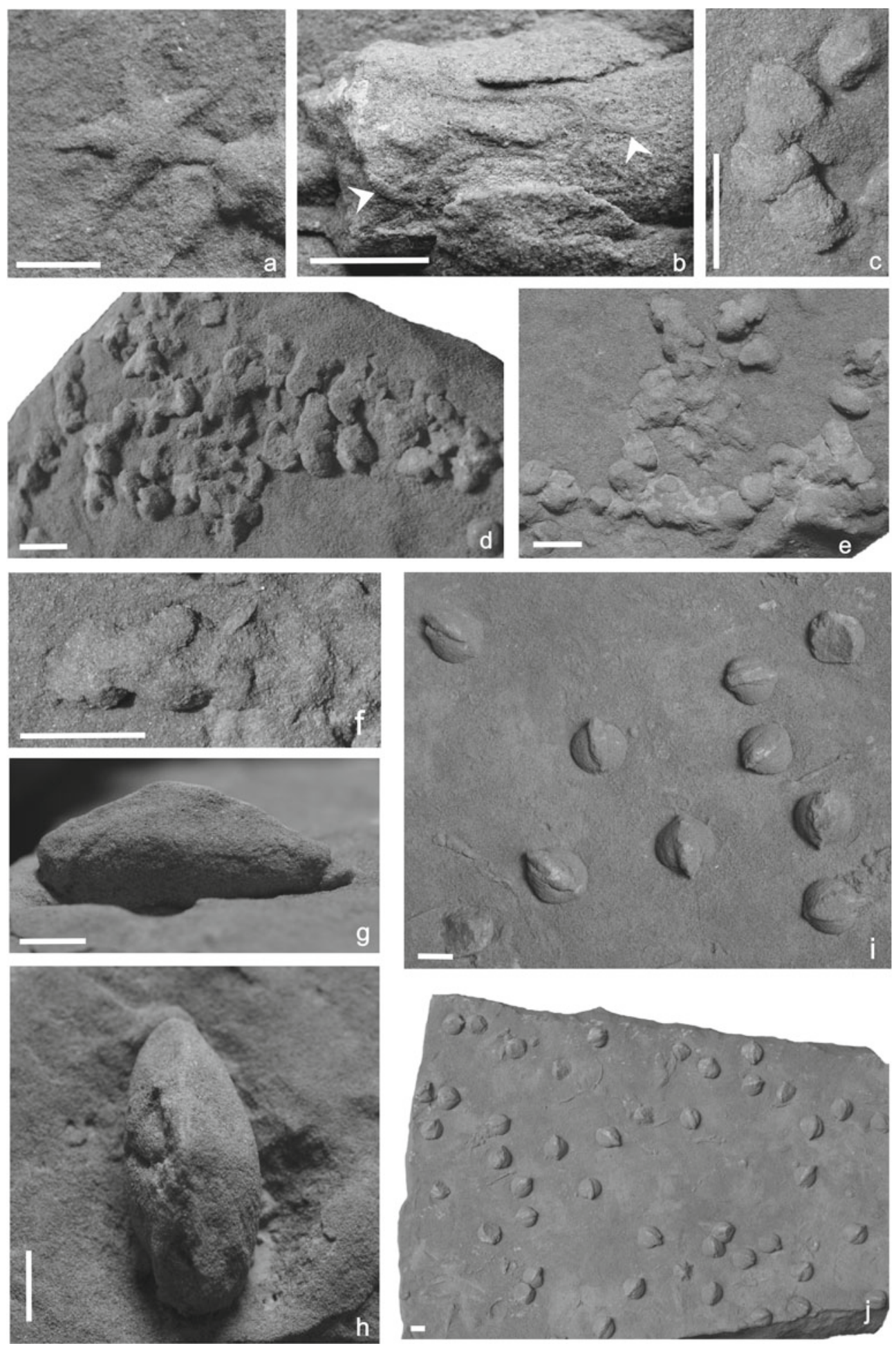

Plate 1. (a) Heliophycus isp. Miller and Dyer 1878 (MACS G 5186), (b) Fossil Ophiuroids (white arrows) (MACS G 5187), (c) Lockeia cunctator Schlirf and Uchman 2001 in cluster (MACS G 5189), (d) Close up of Lockeia cunctator Schlirf and Uchman 2001 (MACS G 5188), (e) Serially arranged Lockeia cunctator Schlirf and Uchman 2001 diverting away from a single axis (MACS G 5188), (f) Club-like arrangement of Lockeia cunctator Schlirf and Uchman (2001) (MACS G 5188), (g) Lockeia siliquaria James 1879 in side view exhibiting a prominent ridge (MACS G 5192), (h) Lockeia siliquaria James 1879 in top view displaying typical almond shape (MACS G 5192), (i) Close up of same slab with Lockeia siliquaria James 1879 exhibiting a prominent keel (MACS G 5194), and (j) Entire slab with keeled, stout Lockeia siliquaria James 1879 (MACS G 5194). (Bar scale: $1 \mathrm{~cm}$. 
at places, exhibit club-shaped arrangement (plate 1f).

Remarks: The specimens agree with the diagnostic features of Lockeia cunctator (Schlirf et al. 2001) such as club or almond-shaped probes arranged in a row, diverging away from the main axis (plate 1e). According to Schlirf et al. (2001), the club-shaped arrangement of $L$. cunctator is attributed to the movement of the bivalve in different directions. In our specimens, as some small solitary Lockeia are found surrounding Lockeia cunctator, it is suggested that they may have been produced either by young bivalves or smaller genera. By their movement in directions away from the main central axis, these traces can be easily differentiated from Ptychoplasma vagans. Their morphology and shape distinguish them from L. siliquaria.

Lockeia siliquaria James 1879

Plate $1(\mathrm{~g}-\mathrm{j})$, Plate $2(\mathrm{a}-\mathrm{h})$

Material: Twenty two slabs with total 127 specimens.

Plesiotypes: MACS G 5192-5196, MACS G 5197b, MACS G 5198b, MACS G 5204b

Description: These are convex, hypichnial, almond-shaped traces. The size varies greatly but the shape remains more or less the same. The traces are broadly symmetrical, elongated and tapering at both ends which are blunt. They show the presence of a central median ridge or crest (plate $1 \mathrm{~g}$ and $\mathrm{h}$ ). The crest is less prominent in the small specimens. The sides of the casts are usually smooth, with few exceptions showing corrugation.

In addition, a morphological variant of $L$. siliquaria was found. These forms are stout; they taper towards one end while the other end is rounded (plate 2c and d). Many of these forms show a prominent keel at the top, in place of the ridge (plate $2 \mathrm{e}$ and $\mathrm{f}$ ). It shows corrugated sides whereas the rest of the cast is smooth (plate $2 \mathrm{~g}$ and $\mathrm{h}$ ).

The traces are $10-40 \mathrm{~mm}$ long, $4-17 \mathrm{~mm}$ wide and $2-18 \mathrm{~mm}$ thick. They do not show any preferred orientation on the bedding, and are commonly gregarious.

Remarks: Diagnostic characters such as elongate to stout, almond-shaped, smooth hypichnial ridges generally showing high-relief, suggested by Schlirf et al. (2001), help in identifying our specimens as Lockeia siliquaria. This ichnospecies has been interpreted as casts of the foot of a bivalve during the protraction phase or the cast of the impression of the shell by Seilacher (1953), Osgood (1970) and Seilacher and Seilacher (1994). The corrugations observed on the sides of the traces may be due to compression of sediments during compaction or the movement of the foot during penetration and anchorage (Mángano et al. 1998). In case of the stout forms at Bada Bagh, only the keel-like portion exhibits corrugations, whereas the rest of the cast is smooth. Hence, we suggest that the basal portion is impression of the shell, while the keel with corrugations is impression of the foot compressing the sediments during anchorage. Seilacher and Seilacher (1994), Schlirf et al. (2001) and Mángano et al. (2002) have argued L. amygdaloides as a preservational variant of $L$. siliquaria. We concur with them and hence identify the stout Bada Bagh specimens under L. siliquaria. This variation in the morphology may reflect difference in the expansion of the bivalve foot during burrowing as interpreted by Radley et al. (1998). More or less all specimens occur isolated. In cases where they have been arranged in a linear fashion, they are better identified as Ptychoplasma vagans.

L. siliquaria is associated with Protovirgularia rugosa, Palaeophycus tubularis and Ptychoplasma vagans.

When associated with chevron traces of Protovirgularia, they have been considered by Seilacher and Seilacher (1994) and Mángano et al. (1998) to be the work of a cleft-footed bivalve. L. siliquaria had been previously interpreted as a cubichnion (Osgood 1970; Häntzschel 1975), but Mángano et al. (2002) have indicated that they represent dwelling traces (domichnia) of suspension feeders or fugichnial responses to changes in the environmental conditions.

\section{?Lophoctenium isp. Richter 1850}

Plate 2(i)

Material: One specimen.

Specimen: MACS G 5198a

Description: The trace represents an irregular surface exhibiting undulatory humps and depressions, displaying a feeble spreiten-like structure developed around Lockeia. The trace is preserved in hyporelief.

Remarks: The trace resembles Lophoctenium of Ekdale and Bromley (2001) to a certain extent. They suggested its emplacement due to the movement of palpal tentacles of the labial palps of bivalve. Another reason for identifying the trace as Lophoctenium is its close association with Lockeia. But as the trace does not show any well preserved diagnostic feature of Lophoctenium its specific determination is deferred. Repetitive probing could be the reason for its spreiten-like structure not being preserved.

Ichnogenus Palaeophycus Hall 1847

Palaeophycus striatus Hall 1852

Plate 2(j, k)

Material: Two slabs with one specimen each.

Plesiotype: MACS G 5199a 

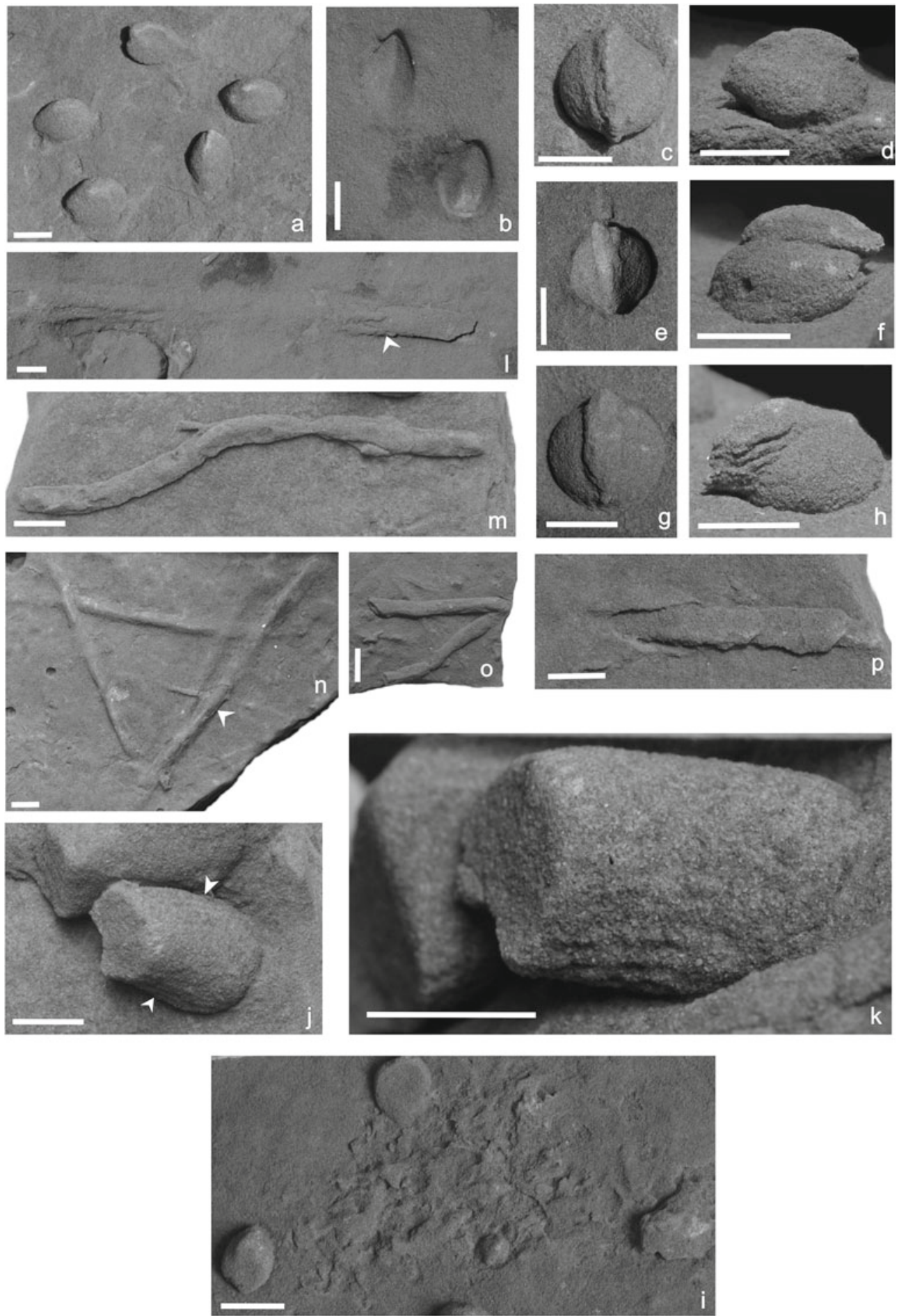

Plate 2. (a) Cluster of Lockeia siliquaria James 1879 (MACS G 5195), (b) Lockeia siliquaria James 1879 with prominent ridge and smooth sides (MACS G 5197), (c) Stout variant of Lockeia siliquaria James 1879 in top view (MACS G 5194), (d) Stout variant of Lockeia siliquaria James 1879 in side view, tapering at one end and rounded at the other end (MACS G 5194), (e) Close up of a single specimen of stout variant of Lockeia siliquaria James 1879 in top view (MACS G 5194), (f) Lockeia siliquaria James 1879 in side view exhibiting a prominent keel (MACS G 5194), (g) Lockeia siliquaria James 1879 in top view with a distinct keel (MACS G 5194), (h) Lockeia siliquaria James 1879 in side view with keel displaying corrugations (MACS G 5194), (i) ?Lophoctenium isp. Richter 1850 surrounded by Lockeia (MACS G 5198), (j) Palaeophycus striatus Hall 1852 exhibiting striae on either sides (white arrows) (MACS G 5199), (k) Close up of Palaeophycus striatus Hall 1852 with parallel striae (MACS G 5199), (1) Palaeophycus tubularis Hall 1847 (MACS G 5197), (m) Palaeophycus tubularis Hall 1847 (MACS G 5199), (n) Cross cutting Palaeophycus tubularis Hall 1847 (MACS G 5200), (o) Palaeophycus tubularis Hall 1847 (MACS G 5201), and (p) Palaeophycus tubularis Hall 1847 (MACS G 5189). (Bar scale: 1 cm.) 
Description: Cylindrical, slightly undulose burrow with distinct parallel longitudinal striations. The burrow is preserved as hypichnial ridge, slightly inclined to the bedding plane. It is circular in cross-section with a diameter of $13 \mathrm{~mm}$ while length is $17 \mathrm{~mm}$. The distance between the striae is $1 \mathrm{~mm}$. The wall lining is weak. The filling of the burrow is same as that of the host rock.

Remarks: As mentioned by Pemberton and Frey (1982), the trace fossil has been distinguished from other ichnospecies by longitudinal parallel striations. Palaeophycus is interpreted as domichnia of suspension feeders or predators, such as polychaetes (Osgood 1970; Pemberton and Frey 1982; Mángano et al. 2005). Its thin lining preserves the open burrow (Gámez-Vintaned et al. 2006).

\section{Palaeophycus tubularis Hall 1847 \\ Plate 2(l-p)}

Material: Nine slabs containing 31 specimens.

Plesiotypes: MACS G 5189b, MACS G 5197a, MACS G 5199b, MACS G 5200-5202

Description: Straight to slightly curved burrows with smooth walls and thin lining, preserved as convex hyporelief. The burrows are horizontal to slightly inclined. The specimens lack branching and are rarely seen to cross each other. They are oval to elliptical in cross-section with their diameter ranging from $2-10 \mathrm{~mm}$. The burrow fill shows the same lithology as that of the host rock.

Remarks: The specimens have been identified as Palaeophycus tubularis and are differentiated from the other ichnospecies of Palaeophycus by its thin wall and the absence of ornamentation (Pemberton and Frey 1982). The ethological interpretation of $P$. tubularis is similar to that of $P$. striatus (Mángano et al. 2005).

Ichnogenus Protovirgularia McCoy 1850

Protovirgularia ?bidirectionalis Mángano, Buatois, West and Maples 2002

Plate 3(a, b)

Material: One specimen.

Plesiotype: MACS G 5204a

Description: The trace shows a curved, meandering, unbranched, hypichnial ridge with chevron traces oriented in opposite directions. The chevron traces show one predominant orientation for most of its path. But at the terminal portion, the Vshaped chevrons are directed opposite to each other. The portion where the change in orientation occurs does not show chevrons. The width of the trace is $4-5 \mathrm{~mm}$ and the trace extends for $190 \mathrm{~mm}$. Remarks: The specimen exhibits diagnostic characters of Protovirgularia bidirectionalis as introduced by Mángano et al. (2002). The trace is differentiated from other ichnospecies by its chevrons oriented in opposite directions. Mángano et al. (2002) have attributed the opposite facing chevrons within a single structure to the reorientation of the animal. It is also mentioned that the structure could have been created in the intertidal region during the flood and ebb process. This concurs with the shallow marine nature of the Bada Bagh Member.

Protovirgularia rugosa Miller and Dyer 1878 Plate 3(c-f)

Material: Four slabs with 15 specimens.

Plesiotype: MACS G 5190b, MACS G 5191b, MACS G 5204c, MACS G 5205

Description: The traces are straight to slightly curved, unbranched, hypichnial ridges with chevrons. All the trails are comparatively short, always emerging from the bivalve cubichnion Lockeia. The structures are horizontal to gently inclined. The chevrons appear as two bilaterally symmetrical appendages diverging from a central axis. The appendages have an arcuate appearance. The chevrons are closely spaced imparting a wrinkled appearance. The appendages show a maximum length of $4 \mathrm{~mm}$. The angle of the appendages with respect to the median line varies for different individuals.

Remarks: The chevrons of Protovirgularia under consideration open away from Lockeia with which they are associated. It indicates movement of the organism away from Lockeia. Some of the traces are slightly inclined and indicate an upward migration. This indicates that it is an escape trace (fugichnion) and thus agrees with the diagnosis of Protovirgularia rugosa given by Seilacher and Seilacher (1994).

Chevrons seen in these specimens are tight and closely spaced, indicating that the substrate was stiff. Hence, the bivalve faced difficulty in locomotion (Mángano et al. 2002).

The association of Lockeia is an ample evidence that Protovirgularia is produced by a bivalve rather than an arthropod (in Mángano et al. 2002) or a scaphopod (Seilacher and Seilacher 1994).

Ichnogenus Ptychoplasma Fenton and Fenton 1937 Ptychoplasma vagans Książkiewicz 1977

Plate 3(g-i)

Material: Two slabs with one specimen each.

Plesiotypes: MACS G 5190a, MACS G 5191a Description: These are elongate, serially aligned amygdaloidal traces in convex hyporelief (plate $3 \mathrm{~h}$ ). The traces are horizontal and aligned in a single plane. Individual specimens are almondshaped, tapering at both ends, about $10 \mathrm{~mm}$ in length and $4-5 \mathrm{~mm}$ in width. They lack the characteristic median longitudinal ridge. Prima facie, the specimen exhibits alternate pinching and swelling (plate $3 \mathrm{~g}$ ). 

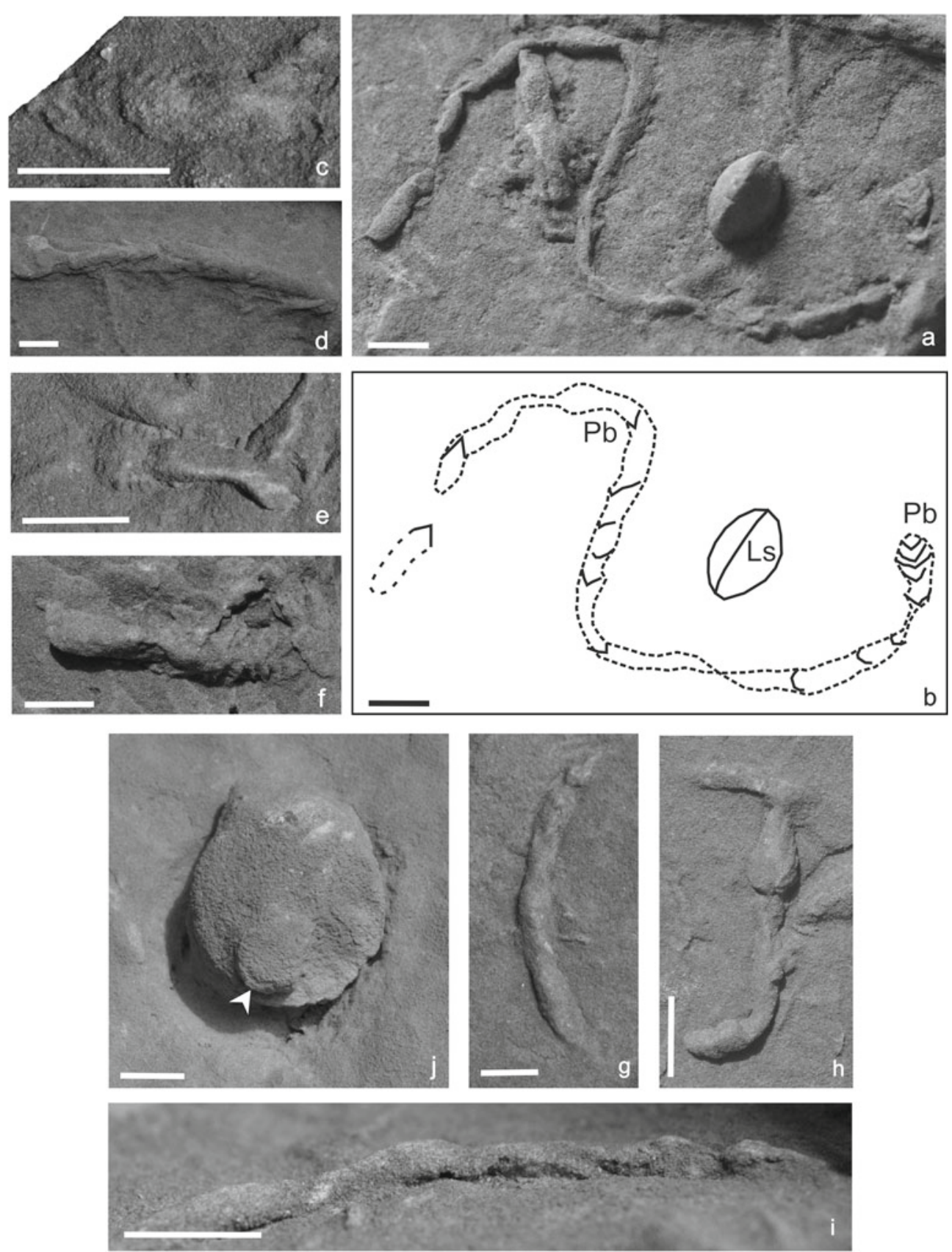

Plate 3. (a) Protovirgularia ?bidirectionalis Mángano, Buatois, West and Maples 2002 (MACS G 5204), (b) Line drawing showing oppositely directed chevron structure of Protovirgularia ?bidirectionalis Mángano, Buatois, West and Maples 2002 (MACS G 5204), (c) Protovirgularia rugosa Miller and Dyer 1878 (MACS G 5191), (d) Protovirgularia rugosa Miller and Dyer 1878 (MACS G 5204), (e) Protovirgularia rugosa Miller and Dyer 1878 moving away from Lockeia (MACS G 5190), (f) Protovirgularia rugosa Miller and Dyer 1878 moving away from Lockeia (MACS G 5205), (g) Ptychoplasma vagans Ksiażkiewicz 1977 in top view, exhibiting pichning and swelling (MACS G 5190), (h) Ptychoplasma vagans Ksiażkiewicz 1977 in top view, exhibiting serially arranged almond-shaped traces (MACS G 5191), (i) Ptychoplasma vagans Ksiażkiewicz 1977 in side view (MACS G 5190), and (j) Unidentified specimen A. Arrow points to the apical protruberance (MACS G 5203). (Bar scale: $1 \mathrm{~cm}$.)

Remarks: This trace can been interpreted as a crawling trace rather than a dwelling structure. The specimens exhibit the diagnostic characters of Lockeia serialis given by Seilacher and Seilacher (1994). Schlirf et al. (2001) assigned a nomen nudum status to $L$. serialis explaining that no holotype, nor illustrations or descriptions of it exists in the literature given by Seilacher and Seilacher (1994) as well as Linck (1949). Uchman et al. (2011) reassigned it to ichnogenus Ptychoplasma highlighting the validity of this ichnogenus over L. serialis. They also stated that 
the ichnogenus Lockeia should be restricted to only the cubichnial traces of bivalves. Uchman et al. (2011) differentiated the three species of Ptychoplasma on the basis of the continuity between bodies. They have described Ptychoplasma vagans as 'mostly discontinuous, Lockeia-like bodies in series'. Hence specimens under consideration are identified as Ptychoplasma vagans.

Ptychoplasma vagans has been reported from all environments ranging from continental, marginalmarine, shallow-marine to deep-sea (Uchman et al. 2011).

The Bada Bagh specimens are commonly associated with L. siliquaria, Protovirgularia.

\section{Unidentified specimen A}

Plate $3(\mathrm{j})$

Material: One specimen.

Repository registration no.: MACS G 5203

Description: Subcylindrical, nearly vertical, feebly pentamerous trace, in positive hyporelief. It exhibits a protuberance at the apical end. The maximum width of the trace is $27.5 \mathrm{~mm}$ and its height is $15 \mathrm{~mm}$. The protuberance is $10 \mathrm{~mm}$ in diameter.

Remarks: The specimen shows close resemblance to ichnogenus Pentichnus. Maerz et al. (1976) have interpreted Pentichnus as dwelling trace of an ophiuroid and they considered pentamerous symmetry to be its most important taxonomic character. The specimen under consideration does not exhibit perfect pentamerous symmetry making its generic identification difficult. All other characters in this specimen, i.e., its subcylindrical form, its occurrence on the sole of the bedding plane and the presence of a protuberance at the apical end are alike the specimens of Pentichnus described by Maerz et al. (1976) and Mángano et al. (2002), respectively.

\section{Numerical analysis}

The use of numerical analysis for the differentiation of various ichnospecies of Lockeia has been attempted by Mángano et al. (1998). For this purpose, a graph of length against width of individual Lockeia specimens is plotted and the respective slopes of different ichnospecies are calculated (figure 3). This analysis serves as an additional ichnotaxonomical tool for the confirmation of different ichnospecies.

The length of $L$. siliquaria ranges from 5.5 to $63 \mathrm{~mm}$, whereas that of $L$. cunctator ranges from 6.5 to $16 \mathrm{~mm}$. This clearly indicates that $L$. siliquaria shows greater variation in length than $L$. cunctator. Even the width range of $L$. siliquaria (4-36 mm) is greater than that of L. cunctator. Thus, as the length increases there is a proportional increase in their width. This is also evident from its average length to width ratio, 1:0.88.

The slopes calculated for the two ichnospecies help in their taxonomic distinction. The slope of the regression line calculated for $L$. siliquaria (0.47) concurs with that suggested for L. siliquaria from the Upper Carboniferous of Eastern Kansas (Mángano et al. 1998). This substantiates our identification of this ichnospecies from the Bada Bagh

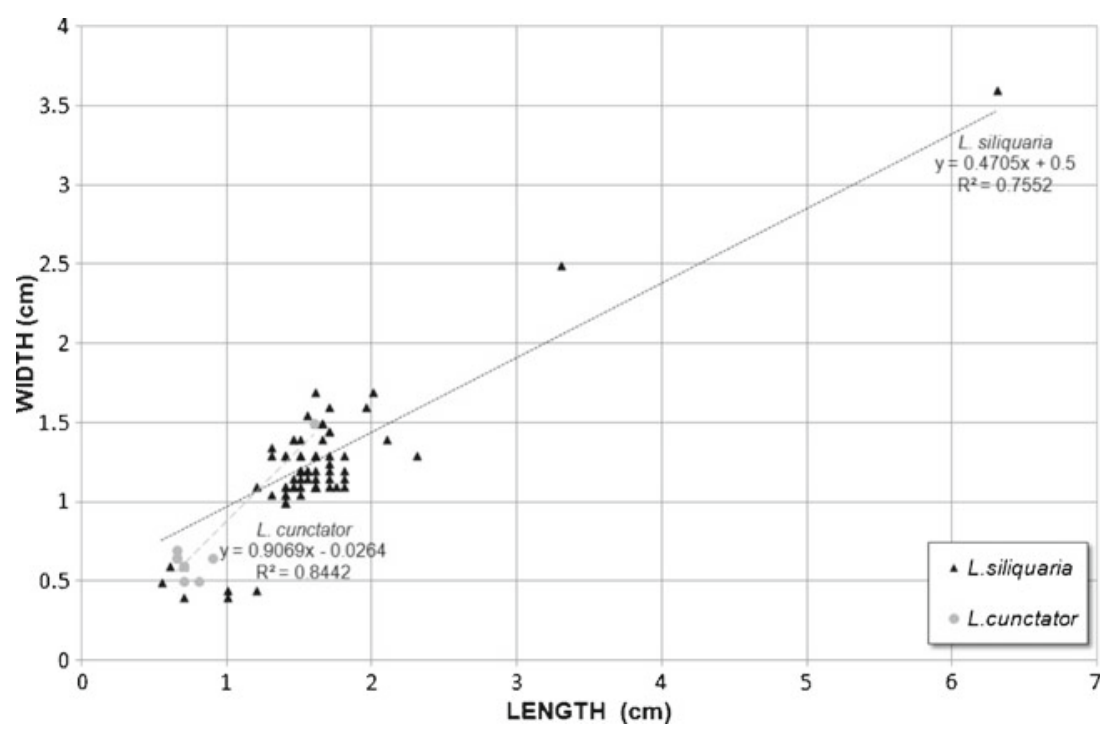

Figure 3. Numerical analysis of the two Lockeia species found. The lines in the graph represent the regression lines for the respective species. 

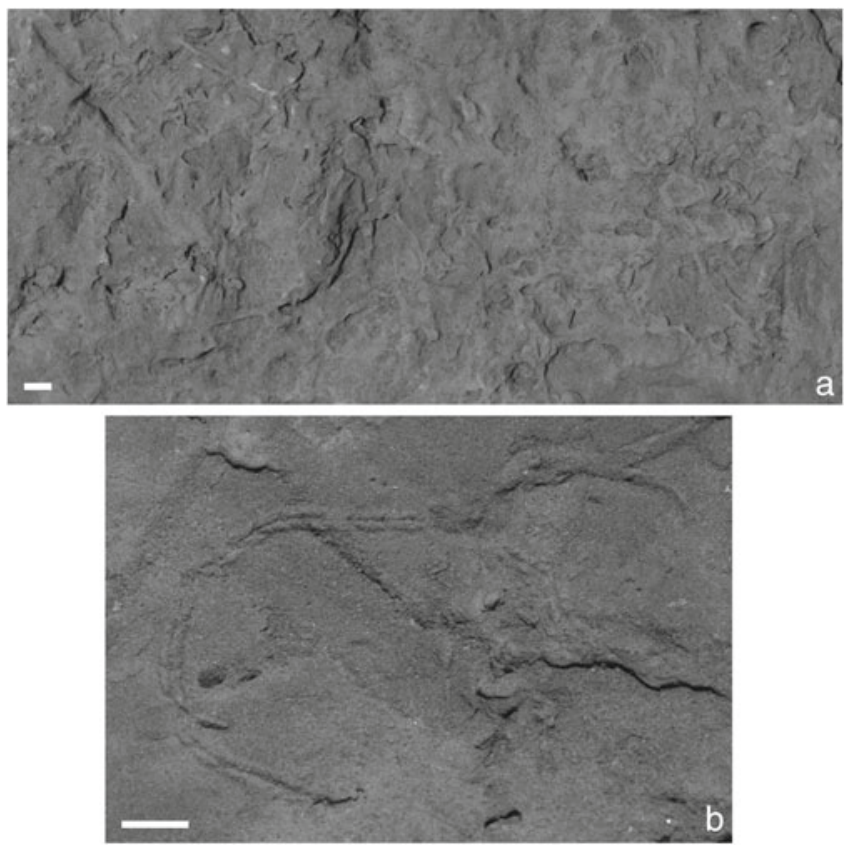

Plate 4. (a) Mottled appearance of the top surface of the bed and (b) Gyrochorte on the top surface of the bed. (Bar scale: $1 \mathrm{~cm}$.)

Member. Mángano et al. (1998) have compared $L$. siliquaria and $L$. ornata using this method. The slope of $L$. cunctator (0.91) exhibits great variation with that of $L$. siliquaria.

Another important parameter here is the coefficient of determination, an overall measure of the accuracy of the trendline or the regression line. A regression line is most accurate when its coefficient of determination value $\left(R^{2}\right)$ is at or near 1 . The coefficient of determination for $L$. siliquaria $(0.75)$ and $L$. cunctator $(0.84)$ is high indicating that the estimated values for the regression line and the actual values are fairly similar (plate 4 ).

\section{Discussion}

It is important to note that all traces described are preserved in convex hyporelief and were collected from the lower bedding plane of single calcareous sandstone under consideration. Their epichnial equivalents could not be found even after a careful investigation. In this connection, it may be pointed out that the $7.35 \mathrm{~m}$ thick calcarenite lithounit, of which the calcareous sandstone is part, is punctuated by a number of thin, silty and clayey intercalations. It is assumed that the traces, Lockeia, Protovirgularia, Ptychoplasma and ?Lophoctenium, seen at the sole of the calcareous sandstone were originally emplaced on the upper bedding plane of such a thin, silty layer. Whenever exposed, this silty layer is eroded away being vulnerable to erosional processes of the desert. This poses difficulty in collecting the original epichnial traces. Nevertheless they are expected to occur in equally great number with satisfactory preservation in the portion hitherto unexposed.

\subsection{Nature of substrate}

The type of substrate and its consistency are affected by a number of factors such as water content, grain size, lithology, sorting, organic content, etc. Of these, the percentage of water present in the sediment serves the key role. With progressive loss of water and consolidation, the same sediment can get transformed serially from a soup-ground to soft-ground, firm-ground and finally with cementation into a hard-ground (Bromley 1996). Consequently, the substrate consistency along with the grain size affects the mode of emplacement of biogenic structures. The remarkable preservation of Lockeia and Protovirgularia in the Bada Bagh Member needs to be seen in this context. L. siliquaria show smooth, well preserved sides and a sharp central longitudinal crest. In the stout variants of $L$. siliquaria (plate $2 \mathrm{c}-\mathrm{h}$ ), the keel looks perfectly distinct from the main body. This indicates that the silty substrate, in which these burrows were emplaced, was compact enough, facilitating preservation of finer details. Moreover, Protovirgularia associated with Lockeia show sharp and closely spaced chevrons, an observation also made by Mángano et al. (2002) in specimens from the Stull Shale Member in Eastern Kansas of Late Pennsylvanian age. They have explained it by envisaging that 'the bivalve faced difficulty and had to struggle to move ahead in a stiff, resistant and dewatered substrate, and therefore had to take short steps', equally applicable to the Bada Bagh specimens. Earlier, Mángano et al. (1998) had indicated that traces with sharp, closely spaced chevrons can be attributed to a firmer soft-ground. Uchman and Pervesler (2006) are also of the opinion that the chances of preservation of morphological details increase with increase in stiffness of the substrate. Trueman (1966) and Schieber (2003) concur with the same. Though, it may be noted here that Buatois et al. (1997) have attributed striated trace fossils such as Palaeophycus striatus to a firm-ground suite. Seilacher and Seilacher (1994) stated that any hypichnial traces do not directly form from casts of the muddy substrate but are more likely to be formed when the muddy substrate has been blanketed by a coarser event deposit. Traces formed in such a manner escape destruction from the current and wave action and exhibit more details being formed in a cohesive substrate. The mechanism discussed by Seilacher 
and Seilacher (1994) is also applicable to the present specimens. Based on the above factors, the authors are inclined to term the substrate as a stiff soft-ground.

In this context, it may be pointed out that the ichnogenera Lockeia, Protovirgularia and Heliophycus from the present ichnoassemblage are believed to belong to the classical Cruziana ichnofacies. Bromley (1996) mentioned that the Cruziana ichnofacies indicates loose and softground substrate with silty to sandy grain size. However, observations regarding the nature of substrate of the silty layer at Bada Bagh are contrary to this generalisation. Therefore, it is suggested that the Cruziana ichnofacies can also occur in stiffer soft-ground.

A change in the nature of substrate is apparent in the lower silty layer and the overlying calcareous sandstone bed. The burrows assigned to Palaeophycus in this bed, associated with Lockeia and Protovirgularia show elliptical cross-section evincing that it was not as compacted as the silty layer. The top of the calcareous sandstone bed shows intense bioturbation which has destroyed the bedding, leading to a non-descript relief. This evinces a change in conditions of deposition. A few Gyrochorte and certain beaded structures are the only trace fossils that could be identified in the crowded assortment of traces. These traces clearly identify upper calcareous sandstone bed to be soft-ground in nature.

\subsection{Environment of deposition}

Lockeia and Protovirgularia are recorded in environments ranging from shallow to deep water, restricting their use in determining the environment. However, in the Bada Bagh Member, they occur in great abundance. It transpires that conditions were extremely conducive for the bivalve community which emplaced them. The bivalves thrived at this locality in a large population. Several cubichnia are associated with repichnia. It implies that ambient settings including food, oxygen and ideal substrate consistency permitted them to proliferate here when the silty layer was being deposited. Dominance of horizontal traces is also indicative of a regular steady input of organic matter (Buatois and Mángano 2011). The ophiuroid resting trace Heliophycus (identified as Asteriacites lumbricalis by earlier researchers) indicates marginal-marine, tidal environment (Hakes 1976; Mángano et al. 1999) with clear waters (Bernardi et al. 2010). Although, Asteriacites has also been found in brackish waters, it typically indicates well oxygenated waters of normal salinity (Mángano et al. 1999). Hence, here it is considered that Heliophycus also indicates a shallow-water environment of deposition. Maerz et al. (1976) have reported it from limestone wherein it occurs in quiet water conditions.

A meticulous search for Lockeia, Protovirgularia and Ptychoplasma in any of the younger or older beds of the Bada Bagh Member, however, was unfruitful. Thus, it construes that the Lockeia-Protovirgularia-Ptychoplasma assemblage described in the foregoing lines was a single colonization event.

Seilacher and Seilacher (1994) have interpreted Protovirgularia rugosa as the response of the organism to storm sand sedimentation, while Mángano et al. (2002) have attributed it to rapid tidal sedimentation. However, in the specimens studied, escape traces were not observed in vertical cross sections. This could be because of the difficulty faced by the cleft footed bivalves to move vertically (Mángano et al. 2002), or it could be interpreted that moderate sedimentation rates were not conducive for the organism to leave any vertical trace.

Vis-à-vis the entire succession of the Bada Bagh Member, the ichnofacies of this calcareous sandstone litho-unit points towards low-medium energy condition under subtidal environment of deposition. Strata underlying this litho-unit show traces such as Arenicolites, Skolithos and Curvolithus which point towards Skolithos ichnofacies, indicating intertidal sandy shore environment with highenergy conditions. Thus, it can be concluded that this area underwent a continuous, gradual deepening. It is also observed that the beds overlying this litho-unit show traces such as Thalassinoides, Ophiomorpha and Phycodes. The percentage of occurrence of these traces (Thalassinoides and Ophiomorpha) is quite large and is thus indicative of an increase in the energy conditions resulting from a probable shallowing.

Further studies on the entire trace fossil assemblage of the Jaisalmer Formation and its integration with sedimentology will favour a better understanding of the sea level dynamics.

\section{Acknowledgements}

This work was carried out under a project sponsored by the Agharkar Research Institute, Pune. The authors sincerely thank the Director, A R I for his support in all respects. They thank the reviewers of this paper, Dr Dirk Knaust and Dr Rodríguez-Tovar, for their valuable and sincere suggestions in improving the manuscript. In addition, they also thank Dr Luis Buatois for his help in identifying the specimens of Lockeia in initial stages and also for providing references. They are 
grateful to Dr V D Borkar for the long discussions and constructive suggestions while preparing the manuscript. Dr Shilpa Patil Pillai's assistance during one field visit is also acknowledged.

\section{References}

Bernardi M, Petti F M and Avanzini M 2010 Palaeoenvironmental implications of Asteriacites lumbricalis in the Coste Dell'anglone Sinemurian Dinosaur Ichnosite (NE Italy); Palaeontologia Electronica 13(3) 1-8.

Bertling M, Braddy S J and Bromley R G 2006 Names for trace fossils: A uniform approach; Lethaia 39(3) 265-286.

Blanford W T 1877 Geological notes on the Great Indian Desert between Sind and Rajputana; Rec. Geol. Surv. India 10 10-21.

Borkar V D and Kulkarni K G 2001 On the occurrence of Rhizocorallium Zenker from the Habur Formation (Aptian), Rajasthan; Gondwana Geol. Mag. 16(1) 15-20.

Borkar V D and Kulkarni K G 2002 Trace fossils from Fatehgarh Formation (?Aptian), Rajasthan; Gondwana Geol. Mag. 17(1) 33-37.

Bromley R G 1996 Trace fossils - Biology, taphonomy and applications (London: Chapman and Hall), 361p.

Buatois L A and Mángano G 2011 Ichnology OrganismSubstrate Interactions in Space and Time (Cambridge: Cambridge University Press), 358p.

Buatois L A, Jalfin G and Aceñolaza F G 1997 Permian nonmarine invertebrate trace fossils from southern Patagonia, Argentina: Ichnologic signatures of substrate consolidation and colonization sequences; J. Paleontol. 7(2) 324-336.

Chiplonkar G W, Ghare M A and Badve R M 1981 On the occurrence of ichnogenus Ichnyspica Linck from Upper Jurassic Jaisalmer Series, Rajasthan; Curr. Sci. 50(3) 147-148.

Das Gupta S K 1975 A revision of the Mesozoic-Tertiary stratigraphy of the Jaisalmer basin, Rajasthan; Indian J. Earth Sci. 2(1) 77-94.

Ekdale A A and Bromley R G 2001 A day and a night in the life of a cleft-foot clam: Protovirgularia-LockeiaLophoctenium; Lethaia 34(2) 119-124.

Gámez-Vintaned J A, Liñán E, Mayoral E, Dies M, Gozalo $\mathrm{R}$ and Muńiz F 2006 Trace and soft body fossils from the Pedroche Formation (Ovetian, Lower Cambrian of the Sierra de Córdoba, S Spain) and their relation to the Pedroche event; Geobios 39 443-468.

Gupta P D, Srivastava M L and Agrawal V C 1966 Occurrence of Nereites, a fossil polychaete (Annelida) in Rajasthan; Curr. Sci. 35(24) 624.

Hakes W G 1976 Trace fossils and depositional environments of four clastic units, upper Pennsylvanian megacyclothems, northeast Kansas; The University of Kansas Palaeontological Contribution 63 1-46.

Häntzschel W 1975 Trace fossils and Problematica; In: Treatise on Invertebrate Palaeontology (ed.) Moore R C; The Geological Society of America and University of Kansas Press, Part W, Miscellanea W177-W245.

Joseph J K, Patel S J and Bhatt N Y 2012 Trace fossil assemblages in mixed siliciclastic-carbonate sediments of the Kaladongar Formation (Middle Jurassic), Patcham Island, Kachchh, Western India; J. Geol. Soc. India 80 189-214.

Kachhara R P and Jodhawat R L 1999 Bivalve biostratigraphy of the Jaisalmer Formation, Western Rajasthan, India; In: Geological Evolution of Northwestern India (ed.) Paliwal B S (Jodhpur: Scientific Publisher), pp. 109-117.
Kumar A 1979 Report on the occurrence of Gyrochorte and other bilobed trace fossils in the Jaisalmer Formation, Rajasthan; Curr. Sci. 48(18) 817-818.

Linck O 1949 Lebens-spuren aus dem Schilfsandstein (Mittl. Keuper km 2) NW-Württembergs und ihre Bedeutung für die Bildungsgeschischte der Stufe; Jahreshefte des Vereins für Vaterländische Naturkunde in Württemberg 97-101, $1-100$.

Maerz R H, Kaesler R H and Hakes W 1976 Trace fossils from the Rock Bluff Limestone (Pennsylvanian, Kansas); The University of Kansas Paleontological Contributions $801-6$.

Mángano G, Buatois L A, West R R and Maples C G 1998 Contrasting behavioral and feeding strategies recorded by tidal-flat bivalve trace fossils from the upper Carboniferous of eastern Kansas; Palaios 13(4) 335-351.

Mángano G, Buatois L A, West R R and Maples C G 1999 The origin and paleoecologic significance of the trace fossil Asteriacites in the Pennsylvanian of Kansas and Missouri; Lethaia 32(1) 7-30.

Mángano G, Buatois L A, West R R and Maples C 2002 Ichnology of a Pennsylvanian Equatorial tidal-flat - The Stull Shale Member at Waverly, eastern Kansas; Kansas Geol. Surv. Bull. 245 1-133.

Mángano G, Buatois L A and Guinea F M 2005 Ichnology of the Alfarcito Member (Santa Rosita Formation) of northwestern Argentina: Animal-substrate interactions in a lower Paleozoic wave-dominated shallow sea; Ameghiniana 42(4) 641-668.

Oldham R D 1886 Preliminary note on the geology of northern Jaisalmer; Rec. Geol. Surv. India 19 157-160.

Osgood R G 1970 Trace fossils of the Cincinnati area; Palaeontographica Americana 6(41) 277-444.

Pandey D K, Sha J and Choudhary S 2010 Sedimentary cycles in the Callovian-Oxfordian of the Jaisalmer Basin, Rajasthan, western India; Volumina Jurassica 8 131-162.

Pemberton S G and Frey R W 1982 Trace fossil nomenclature and the Planolites-Palaeophycus dilemma; J. Paleontol. 56(4) 843-881.

Radley J D, Barker M J and Munt M C 1998 Bivalve trace fossils (Lockeia) from the Barnes High Sandstone (Wealden Group, Lower Cretaceous) of the Wessex Subbasin, southern England; Cret. Res. 19(3-4) 505-509.

Schieber J 2003 Simple gifts and buried treasures; implications of finding bioturbation and erosion surfaces in black shales; The Sedimentary Record 1 4-8.

Schlirf M 2012 Heliophycus seilacheri n. isp. and Biformites insolitus Linck, 1949 (trace fossils) from the Late Triassic of the Germanic Basin: Their taxonomy and palaeoecological relevance; Neues Jahrbuch für Geologie und Paläontologie, Abhandlungen 263(3) 185-198.

Schlirf M, Uchman A and Kümmel M 2001 Upper Triassic (Keuper) non-marine trace fossils from the Haßberge area (Franconia, southeastern Germany); Paläontologische Zeitschrift 75(1) 71-96.

Seilacher A 1953 Studien zur Palichnologie II Die fossilien Ruhespuren (Cubichnia); Neues Jahrbuch für Geologie und Paläontologie, Abhandlungen 98 87-124.

Seilacher A and Seilacher E 1994 Bivalvian trace fossils: A lesson from actuopalaeontology; Courier Forschungsinstitut Institut Senckenberg 169 5-15.

Singh N P 2006 Mesozoic lithostratigraphy of the Jaisalmer Basin, Rajasthan; J. Palaeontol. Soc. India 51(2) 1-25.

Sudan C S, Sahni A K and Sharma U K 2000 Trace fossils from the Jurassic sequence of Jaisalmer basin, Rajasthan; J. Palaeontol. Soc. India 45 165-171.

Trueman E R 1966 Bivalve mollusc: Fluid dynamics of burrowing; Science 152 523-525. 
Uchman A and Pervesler P 2006 Surface Lebensspuren produced by Amphipods and Isopods (Crustaceans) from the Isonzo delta tidal flat, Italy; Palaios 21 384-390.

Uchman A, Mikulás R and Rindsberg A K 2011 Mollusc trace fossils Ptychoplasma Fenton and Fenton, 1937 and Oravaichnium Plička and Uhrová, 1990: Their type material and ichnospecies; Geobios 44 387-397.

Wilson M A and Rigby K 2000 Ichnologic note Asteriacites lumbricalis von Schlotheim 1820: Ophiuroid trace fossils from the Lower Triassic Thaynes Formation, central Utah; Ichnos 7(1) 43-49.

MS received 9 November 2011; revised 14 March 2013; accepted 14 March 2013 